\title{
Dorota Leszczyna, Hegel w Hiszpanii. Od szkoły sewilskiej do szkoły madryckiej, Wydawnictwo Marek Derewiecki, Kęty 2017, ss. 582
}

Recenzowana przeze mnie książka jest wyjątkowa pod wieloma względami. Przede wszystkim mamy do czynienia z bardzo rzetelną pracą znakomitego historyka filozofii, którego warsztat można tylko podziwiać. Co najważniejsze stanowi ona niezwykle obszerne kompendium wiedzy na temat wpływu myśli Heglowskiej na filozofię hiszpańską. Jak dotąd nie było takiej pozycji nie tylko wśród publikacji polskojęzycznych, ale także światowych. Zazwyczaj możemy spotkać się z rozprawami podejmującymi tę tematykę w ramach czasowych ograniczonych do XIX lub XX wieku, w tym drugim przypadku zazwyczaj badania zawężają się do filozofii Ortegi y Gasseta. Chociaż książka ma charakter historyczno-filozoficzny, to nie jest jedynie suchym kompendium relacjonującym chronologicznie dokonania poszczególnych myślicieli. Rozważania filozoficzne przedstawione są bowiem na tle dziejów społecznych i politycznych przemian, jakie dokonują się w niezwykle burzliwej historii narodu hiszpańskiego, a poprzez nie autorka ukazuje także, jak ważna dla rozwoju kultury każdej narodowości jest otwartość na inne kultury, przy jednoczesnym zachowaniu własnej tożsamości. Zwłaszcza, że oddziaływanie myśli Heglowskiej, czego możemy dowiedzieć się z recenzowanej pozycji, w drugiej połowie XIX wieku ma charakter raczej społeczno- polityczny niż czysto filozoficzny, przez co odegrała ona bardzo ważną rolę w kształtowaniu się współczesnych struktur politycznych, państwowych, religijnych i kulturowych.

Książka Hegel w Hiszpanii została przez samą autorkę podzielona na dwie części: pierwsza obejmuje okres drugiej połowy XIX wieku (szkołę sewil- 
ską), druga odnosi się do pierwszej połowy XX wieku i dotyczy myśli Ortegi y Gasseta oraz jego uczniów.

Sytuacja w Hiszpanii połowy XIX wieku była niezwykle trudna. Przez elity intelektualne była postrzegana jako zacofana i wymagająca gruntownej naprawy; dotyczyło to zwłaszcza systemu religijnego, politycznego i prawnego. Z tego powodu najistotniejsze dla klasy średniej okazały się zasady Heglowskiej filozofii prawa i państwa, które stwarzały nadzieję na modernizację archaicznej państwowości, stawały się narzędziem rewitalizacji życia kulturalnego, wzniesienia poziomu intelektualnego społeczeństwa do poziomu europejskiego, zbudowania silnej społeczności obywatelskiej, a także sprzyjały dążeniom wolnościowym i republikańskim. Myślicielom hiszpańskim chodziło przede wszystkim o zniesienie monarchii i stworzenie republiki, jednak różnili się co do kierunku obranych reform, w zależności od tego, czy reprezentowali poglądy prawicowe (Emillio Castelsra y Ripolla, Antonio Beniteza de Lugo) czy lewicowe (Francisco Pi y Margalla i Pablo Correa y Zafrilla). Co ciekawe, wśród propagatorów myśli heglowskiej znajdowali się też monarchiści jak Antonio Maria Fabié Escudero, a także osoby, których nie sposób zaliczyć do określonych kierunków politycznych (Rafael Calixto Montoro y Valdésa, Miguel de Unamuno y Jugo). Każdemu z tych filozofów autorka poświęca część książki, pokazuje, w jaki sposób poglądy ich ścierały się ze sobą, jak poszczególne idee wpływały jedna na drugą, by w ostatecznym rozrachunku stworzyć podwaliny pod nową kulturę swego narodu.

Autorka książki ukazuje rozważania i dyskusje filozoficzne na tle zdarzeń społecznych i kulturalnych, a druga połowa XIX wieku to jeden z najbardziej burzliwych okresów w historii Hiszpanii, kiedy to dotychczasowy porządek prawny i państwowy został powszechnie zanegowany przez społeczeństwo niemogące znieść drugiego panowania despotyzmu monarchicznego, korupcji, braku tolerancji religijnej. W końcowym rezultacie zaowocowało to krwawymi rewolucjami, buntami, wojnami domowymi, powstawaniem i upadkami rządów. Dorota Leszczyna pokazuje nam, że recepcja Hegla w takiej sytuacji musiała być bardziej pragmatyczna niż teoretyczna, nieco pobieżna i uproszczona, a często także eklektyczna, przemieszana $\mathrm{z}$ takimi nurtami myśli społecznej, jak liberalizm, socjalizm czy republikanizm, z myślą takich filozofów, jak Jeremi Bentham, Ludwig Feuerbach, Pierre-Joseph Proudhon, wreszcie mocno skoncentrowana na filozofii prawa i państwa. Autorka książki jest także świadoma tego, że wielu spośród myślicieli hiszpańskich XIX wieku nie znało języka niemieckiego na tyle, by móc swobodnie zaznajomić się z filozofią heglistów bezpośrednio, ale że musieli oni 
korzystać z przekładów na język francuski lub włoski. W związku z tym Dorota Leszczyna była zmuszona sięgnąć także po wspomniane tłumaczenia i opracowania, co też uczyniła, zgodnie z rzetelnym warsztatem historyka filozofii. Pokazuje również sylwetki niezwykle ciekawych hiszpańskich filozofów, którzy wyjeżdżali na stypendia do Niemiec, aby móc studiować dzieła bezpośrednio u „źródeł”. Tak było w przypadku Juliána Sanz de Rio, który przebywał w Heidelbergu oraz José del Perojo y Figueras, który przygotował i obronił doktorat u Kuno Fischera. Zwłaszcza ten ostatni jest ciekawą postacią, autorem pierwszego przekładu Krytyki czystego rozumu i założycielem czasopisma „Revista Contemporánea” oraz wydawnictwa, gdzie wydawane były przekłady pism filozofów nowożytnych: Kartezjusza, Leibniza, Kanta, Schellinga i oczywiście Hegla. Poprzez czasopismo i wydawnictwo kręgi intelektualistów mogły wpływać na myślenie swych rodaków, zaszczepiać im idee tolerancji i umiłowanie wolności. Proces zmiany świadomości też dokonywał się stopniowo poprzez określonych przedstawicieli hiszpańskiej filozofii; autorka podzieliła go na kilka okresów.

Pierwszy okres przypada na lata 1850-1868 i jest związany z aktywnością naukowców na Uniwersytecie w Sewilli: José Contero y Ramirez, Diego Álvarez de los Corrales Malgarejo, Francisco Roque Barcia i Francisco Escudero y Perosso. Ich odczytywanie Hegla łączyło polityczno-prawne aspekty jego filozofii.

Drugi okres obejmuje lata porewolucyjne, związane z powstaniem Republiki Hiszpańskiej. Autorka przedstawia recepcję myśli Hegla, jaka dokonuje się za sprawą dwóch filozofów i polityków: Castelara y Ripolla, reprezentującego nurt prawicowy, i Pi y Margalla z lewicy, który łączył idee heglowskie z myślą Feuerbacha i Proudhona. W tym czasie działa także kontynuator szkoły sewilskiej Benitez de Lugo, który prowadzi systematyczne badania nad zasadami filozofii prawa Hegla.

Trzeci okres to lata 1874-1885, kiedy działa konserwatywny polityk Fabié Escudero, tłumacz Logiki Hegla oraz Kubańczyk Montoro y Valdésa.

Czwarty okres, Regencja, przypada na lata 1885-1902 i wiąże się z pierwszym przekładem Kapitału Marksa dokonanego przez Correi y Zafrilli oraz z działalnością grupy „Pokolenia 1898” (Unamuno y Jugo, Antonio Machado y Ruiz, Pio Baroja y Nessi, Ramiro de Maeztu y Whiney, Valle Inclán). Grupa ta charakteryzowała się postawą krytyczną wobec racjonalizmu i zwracała się raczej ku koncepcjom witalnym i irracjonalnym. W tej części najciekawszy podrozdział poświęcony jest wczesnym rozważaniom Unamuno y Jugo i jego filozofii sentymentalizmu, w których stwierdza, że światem myśli kierują nie 
pojęcia, ale uczucia i sentymenty. Leszczyna pokazuje wpływ filozofii logiki Hegla na wizję „wiecznej tradycji” (tradición eterna) w myśleniu Unamuno.

Recepcja Hegla znakomicie obrazuje, w jaki sposób dochodzi do zmian w kulturze danego państwa, a także jak ważna jest otwartość na odmienny sposób myślenia przy jednoczesnym zachowaniu własnej tożsamości i specyfiki swojego sposobu myślenia. Zwłaszcza okres drugiej połowy XIX wieku w Hiszpanii przedstawiony przez autorkę znakomicie spełnia to zadanie. Leszczyna pokazuje kraj monarchiczny, silnie zakorzeniony w tradycji religijnej, w którym dochodzą do głosu pragnienia daleko idących przemian ustrojowych związanych $\mathrm{z}$ dążeniem do wolności i marzeniami o republice. Ukazuje go jednak od strony recepcji myśli filozoficznej, zwracając uwagę na to, w jaki sposób idee myślenia abstrakcyjnego splatają się z praktyką społeczną i przyczyniają się do innego myślenia o prawie i zasadach państwowości. Pierwsza recepcja filozofii Hegla właśnie przez to, że jest oderwana od rozważań czysto metafizycznych pozwala intelektualistom hiszpańskim przenieść myślenie rdzennie niemieckie i protestanckie na grunt ich własnej kultury i przyczynić się do zmian dotyczących rewitalizacji organów państwowych i nowych praw. Z pierwszej części książki wyraźnie wynika, że kultura (każda, nie tylko hiszpańska) rozwija się z napięcia między dwoma biegunami. Z jednej strony, aby doszło do zmian, musi być ona otwarta, kosmopolityczna, ale nie może biernie przejmować obcych idei i bezrozumnie wplatać ich we własne życie. Takie działania odnotowano na przykład w historii XVIII-wiecznej Polski, kiedy szlachta przyjmowała wzorce obcych mocarstw, zapominając często o własnych korzeniach i specyfice społeczno-kulturowej. W XIX-wiecznej Hiszpanii dokonało się coś przeciwnego: myśl przeniesiona $\mathrm{z}$ innych państw zyskała specyficzny charakter, zgodny z lokalnym rysem narodowym, i stała się niezwykle twórcza, zdolna zmienić mentalność ludzi i doprowadzić do zmian ustrojowych. Dopiero wówczas recepcja Hegla nabrała innego znaczenia i temu poświęcona jest druga część książki.

W pierwszej połowie XX wieku nastąpiło przejście od praktycznej i wybiórczej recepcji myśli Hegla do systematycznych studiów nad jego filozofią. Zwrot ten dokonał się według autorki za sprawą najbardziej znanego z myślicieli hiszpańskich Ortegi y Gasseta. Filozof ten nie tylko prowadził badania nad niemiecką myślą, ale także zadbał o jej szerszą recepcję w swojej ojczyźnie. W 1923 roku założył wydawnictwo i czasopismo „Revista de Occidente”, w którym regularnie ukazywały się teksty z filozofii niemieckiej: przekłady Hegla, artykuły i recenzje podejmujące tematykę związaną z jego myślą, a także informacje związane ze współczesnymi nurtami filozofii europejskiej. 
Działalność ta, rozpoczęta w okresie międzywojennym rozwija się do dziś, czego najlepszym przykładem jest założone w 1996 roku na Uniwersytecie w Salamance Hiszpańskie Towarzystwo Heglowskie.

Druga część książki w znacznej mierze poświęcona jest filozofii Ortegi y Gasseta, ale oprócz niego pojawiają się też inne nazwiska hiszpańskich badaczy: Zubiriego Apalategui, Juliána Maríasa Aguilery i José Gaosa y Gonzáleza-Pola. Także tę część podzieliła autorka książki na cztery okresy, które odzwierciedlają zmiany, do jakich dochodziło w myśleniu Ortegi y Gasseta od świadomej recepcji myśli niemieckiej po krytyczne spojrzenie, aż wreszcie stworzenie nowego, własnego już systemu filozoficznego, powstałego w wyniku problemów i potrzeb hiszpańskiego narodu. Ponownie zatem czytelnik będzie mógł zobaczyć, jak kosmopolityzm i otwartość przy jednoczesnej świadomości własnej przynależności narodowej rodzi nowy, niepowtarzalny sposób myślenia.

Pierwszy etap XX-wiecznych badań nad myślą Hegla przypada na lata 1902-1915 i jest związany z działalnością młodego Ortegi i poglądami grupy „Pokolenia 1898”. Dyskusja pomiędzy Unamuno y Jugo i Maeztu y Whitneyem a Ortegą y Gassetem toczyła się na łamach hiszpańskich dzienników „ABC”, „El Faro” i „Nuevo Mundo” oraz poprzez listy w latach 1908-1909. Polemiki te dotyczą sposobu uprawiania filozofii, a przede wszystkim sposobu rewitalizacji hiszpańskiej kultury i społeczeństwa poprzez recepcję myśli niemieckiej. W największym uproszczeniu: Ortega, stojąc na stanowisku racjonalistycznym i mocno zakorzenionym $\mathrm{w}$ niemieckim idealizmie, pragnął większej systematyzacji i dyscypliny dla hiszpańskiego życia intelektualnego, natomiast reprezentanci „Pokolenia 1898” bliżsi byli tendencjom irracjonalnym i zindywidualizowanym i chcieli odrodzenia ojczyzny w duchu własnej tradycji, nie pragnęli zakorzenienia idei własnego kraju w myśleniu wywodzącym się z naukowych i politycznych tradycji innych narodowości. Spór ten dotyczy raczej kwestii wyważenia pomiędzy kosmopolityzmem a narodową myślą, tego, czemu przyznać więcej racji: ideom własnym czy myśli zrodzonej w innej społeczności. Wszystkie te rozważania oscylowały wokół idei nowego liberalizmu i tego, jak bardzo powinien on być zakorzeniony w myśleniu narodu, a na ile powinien przybrać formy wypracowane w innych kulturach.

Drugi etap rozwoju hiszpańskiej myśli nad filozofią Hegla obejmuje lata 1916-1927 i związany jest z rozwojem filozoficzno-politycznej działalności Ortegi y Gasseta oraz z jego rozważaniami nad problematyką filozofii dziejów zespoloną z koncepcją narodowego liberalizmu. W warstwie praktycznej 
hiszpański filozof walczył wówczas z ideami progresistów zakorzenionych $\mathrm{w}$ pozytywizmie i postrzegających postęp $\mathrm{w}$ kategoriach utylitarnych. Z drugiej zaś strony ze zwolennikami abstrakcyjnego liberalizmu budującymi utopijne wizje społeczności. Na podstawie tych dyskusji Ortega wypracowuje swoją własną wizję państwowości nazywaną przez niego „polityką realistyczną" lub „polityką realizacji” związanej z koniecznością przełamania subiektywizmu, z wprowadzoną przez niego kategorią życia jako dynamicznej wspólnoty człowieka i świata.

Trzeci etap to lata 1928-1931, kiedy to Ortega nie zajmuje się już ukazywaniem podstaw filozofii Hegla, ale próbuje główne jej myśli wprzęgnąć we własną problematykę filozoficzną. Zaowocowało to krytycznym spojrzeniem na filozofię dziejów Hegla i wprowadzenie na jej miejsce nauki zwanej historiologią oraz z budowaniem własnego projektu filozofii życia.

Czwarty, ostatni, okres przypada na lata 1932-1955. Jest to czas dojrzałej filozofii Ortegi y Gasseta oraz badań nad Heglem, jakie przeprowadzają jego uczniowie. Wówczas to powstaje specyficzna metoda dialektycznego rozumienia życia i społeczności. Z jednej strony przybiera ona formę dialektyki międzypokoleniowej, konfrontację myśli rodziców i dzieci, z drugiej zaś strony dialektyki wewnątrzpokoleniowej, zrodzonej z napięcia między wybitnymi jednostkami, zdolnymi do tworzenia idei a tymi, którzy myśli te odbierają i realizują w życiu, później zaś także z dialektyki rodzącej się pomiędzy człowiekiem masowym a arystokratyczną mniejszością. Relacje te, według Ortegi stanowiące podstawę zdrowego społeczeństwa, zostały zaburzone przez zjawisko buntu mas. Obserwacje te z kolei doprowadziły hiszpańskiego myśliciela do konieczności przewartościowania problemów związanych z liberalizmem i demokracją.

Autorka recenzowanej pozycji jest znakomitym historykiem filozofii, który przykłada dużą wagę do badań źródłowych. Książka Hegel w Hiszpanii jest pozycją o charakterze zdecydowanie naukowym, bardzo drobiazgowo analizującym materiał źródłowy, z tego też względu zainteresuje przede wszystkim historyków i filozofów. Warto jednak, aby sięgnął po nią również każdy interesujący się współczesną kulturą i polityką hiszpańską.

Kinga Kaśkiewicz Uniwersytet Mikołaja Kopernika, Toruń, Polska kinga72@umk.pl 